\title{
ANTHROPOGENIC ACTIVITIES AS A SOURCE OF HIGH PREVALENCE OF ANTIBIOTIC RESISTANT STAPHYLOCOCCUS AUREUS IN THE RIVER GANGA.
}

\author{
ANCHAL SOOD ${ }^{1}$ - PIYUSH PANDEY ${ }^{1,2}$ - - SANDEEP BISHT ${ }^{1}$ - SHIVESH SHARMA ${ }^{1,3}$ \\ ${ }^{I}$ Department of Microbiology, Sardar Bhagwan Singh Post Graduate Institute of Biomedical \\ Sciences and Research, \\ Balawala, Dehradun, UK, 248161, India \\ ${ }^{2}$ Department of Microbiology, Assam University, \\ Silchar, Assam-788011 India (present address) \\ ${ }^{3}$ Department of Applied Mechanics, Motilal Nehru National Institute of Technology, \\ Allahabad (UP) India. (present address) \\ *Corresponding author \\ e-mail:piyushddn@gmail.com \\ (Received 22 $2^{\text {nd }}$ Aug 2010; accepted 22 $2^{\text {nd }}$ July 2014)
}

\begin{abstract}
The presence, distribution and antibiotic profile of staphylococci was determined in River Ganga in Uttarakhand region (India). A total of 128 staphylococcal strains were obtained from 32 sites which corresponded to three species namely S. aureus, S. hominis and S. aegilis. S. aureus dominated the staphylococcal population comprising of $68.75 \%$ of the total staphylococci. The sensitivity of staphylococcal isolates against twelve antibiotics was determined. Majority of the isolates were resistant for erythromycin, while $17.6 \%$ of S. aureus were resistant to methicillin. Interestingly, $93 \%$ of methicillin resistant Staphylococcus aureus (MRSA) was observed to be in the lower regions of river Ganga of Uttarakhand, facing severe anthropological activities. Water of the River Ganga is extensively used for drinking, religious bathing and cleaning purposes. However, the presence of pathogenic multiple drug resistant staphylococci indicate that direct consumption of untreated Ganga water and bathing in this stretch poses a great health risk.
\end{abstract}

Keywords: S. aureus, Ganga, antimicrobial resistance, methicillin resistant Staphylococcus aureus (MRSA)

\section{Introduction}

The surface waters in populous countries have become reservoirs of antimicrobialresistant pathogenic microbes due to indiscriminate use of antimicrobials in human and veterinary medicine and addition of faecal contamination through point as well as nonpoint sources, storm drain infrastructure and malfunctioning septic trenches [1]. The number of antimicrobial-resistant (AMR) bacteria in the environment increases exponentially with the misuse of antimicrobials, as a result of increasing selective pressure on bacterial populations [25, 39]. Furthermore, reports of AMR are increasing continuously, and its spread between various distantly related bacterial strains in different habitats is well established [17, 40,41]. The spread of AMR into environments where antibiotics are not used is a possibility that has not yet been well researched, although it has been postulated that water can be a potential source for dissemination of AMR [42]. The presence of AMR in aquatic sources is now considered an area of serious concern for human public health [20]. Recently, a dramatic increase in the resistance against antibiotics routinely used in human as well as in veterinary medicine 
has been recorded for the members of the genus Staphylococcus. Development of resistant or multiresistant staphylococci strains causes considerable therapeutic problems [29]. In fact, staphylococci are predominant pathogens in hospital-acquired infections, as hospital outbreaks due to methicillin-resistant Staphylococcus aureus (MRSA) have become a major problem in nososcomial infections [9, 32]. More recently, community-acquired MRSA has been documented among healthy individuals without any predisposing risk factors [16]. The recent increase in the resistance of staphylococcal isolates against antibiotics is alarming. Studies have established that contaminated sea and river water may serve as potential reservoirs of healthcare and community-associated MRSA, if such water sources become contaminated with these organisms [38].

The river Ganga is a major river of Indian subcontinent traversing $2510 \mathrm{~km}$ across the country. The river and its tributaries provide $40 \%$ of water requirement of the country for various purposes including irrigation, daily use and drinking [18]. In addition mass bathing in sacred water of Ganges is an age-old ritual in India. Organized outdoor bathing is an important in situ utilization of water bodies, which demands water quality requirements for drinking as well as bathing purposes [31]. There are several reports concentrated on the detection and survival of coliforms in the water of river Ganga [22]. Also, presence of multiple antimicrobial resistant E. coli has been reported from selected locations of river Ganga [28]. Several other members of Enterobactericeae and potential pathogenic genera in river Ganges of Uttarakhand (India) was reported [35] However; there is paucity of information on the presence and concentration of staphylococci and associated antimicrobial resistance in river Ganga. Therefore, this study aimed to isolate and characterize staphylococci, contextualize the dissemination of species diversity, along with determination of their antimicrobialresistance profile along river Ganga in northern India (Uttarakhand).

\section{Materials and methods}

\section{Study area and Sample Collection}

The Gangetic River System of Uttarakhand was intensively surveyed to select different sites for sample collection. The study area was divided into three different stretches i.e. upper, middle and lower stretch. While Bhagirathi and Alaknanda both comprised upper and middle stretches, one in each tributary, the lower stretch was predominantly of Ganga, i.e. downstream to Devprayag (Sangam) till Haridwar (Figure 1). The total stretch covered in this study was $440 \mathrm{Km}$, out of which Alaknanda comprised a stretch of $200 \mathrm{Km}$, Bhagirathi comprised a stretch of $170 \mathrm{Km}$ and Lower Ganga comprised a stretch of $70 \mathrm{Km}$.

The study was performed along 32 towns (Figure 1) situated on the banks of river Ganga in the state of Uttarakhand having the geographical coordinates of latitude in between $29^{\circ} 58^{\prime}-31^{\circ} 03^{\prime} \mathrm{N}$ and longitude $78^{\circ} 13^{\prime}-79^{\circ} 57^{\prime} \mathrm{E}$ (Table 1). The water samples were collected from selected 32 sites, in triplicate from margins and in the middle of the river; about $30 \mathrm{~cm}$ depth in $1000 \mathrm{~mL}$ sterilized bottles and were transported on ice to the laboratory. Physicochemical parameters such as $\mathrm{pH}$ and water temperature were determined using standard methods (4). 


\section{Isolation, enumeration and characterization of staphylococci}

The strains were isolated by the direct plating (DP). Samples were serially diluted in sterile $0.85 \%$ saline and aliquots of $0.1 \mathrm{ml}$ were surface plated on mannitol salt (MS) agar [36] and Baird Parker (BP) agar medium [5], incubated at $37^{\circ} \mathrm{C}$ for $24 \mathrm{~h}$. After $24 \mathrm{~h}$ presumptive colonies were counted. Grey to black colonies, with or without halos, from each BP plate, and off white cream to yellow coloured colonies from MS agar were selected and transferred to slants of Tryptic Soy Agar, incubated overnight at $37^{\circ} \mathrm{C}$.

Table 1. Different sites of sample collection and physical characteristics of water at respective sites

\begin{tabular}{|c|c|c|c|c|}
\hline $\begin{array}{l}\text { Site } \\
\text { Number }\end{array}$ & Name & Geographic location & $\mathrm{pH}$ & $\begin{array}{l}\text { Temperature } \\
\left({ }^{\circ} \mathrm{C}\right)\end{array}$ \\
\hline 1. & Badrinath & $79^{\circ} 32^{\prime} \mathrm{E} ; 30^{\circ} 44^{\prime} \mathrm{N}$ & 7.2 & 1.2 \\
\hline 2 & Hanuman Chatti & $79^{\circ} 31^{\prime} \mathrm{E} ; 30^{\circ} 42^{\prime} \mathrm{N}$ & 6.5 & 1.4 \\
\hline 3 & Pandukeshwar & $79^{\circ} 34^{\prime} \mathrm{E} ; 30^{\circ} 39^{\prime} \mathrm{N}$ & 6.8 & 1.6 \\
\hline 4 & Vishnu Prayag & $79^{\circ} 57^{\prime} \mathrm{E} ; 30^{\circ} 57^{\prime} \mathrm{N}$ & 7.4 & 5.6 \\
\hline 5 & Chamoli & $79^{\circ} 21^{\prime} \mathrm{E} ; 30^{\circ} 24^{\prime} \mathrm{N}$ & 7.2 & 8.7 \\
\hline 6 & Nand Prayag-Nandakini & $79^{\circ} 19^{\prime} \mathrm{E} ; 30^{\circ} 19^{\prime} \mathrm{N}$ & 7.8 & 20.7 \\
\hline 7 & Nand Prayag-Sangam & $79^{\circ} 19^{\prime} \mathrm{E} ; 30^{\circ} 19^{\prime} \mathrm{N}$ & 7.8 & 17.6 \\
\hline 8 & Karan Prayag-Alaknanda & $79^{\circ} 15^{\prime} \mathrm{E} ; 30^{\circ} 16^{\prime} \mathrm{N}$ & 7.6 & 17.6 \\
\hline 9 & Karan Prayag-Pinder & $79^{\circ} 15^{\prime} \mathrm{E} ; 30^{\circ} 16^{\prime} \mathrm{N}$ & 7.5 & 22.8 \\
\hline 10 & Karan Prayag-Sangam & $79^{\circ} 15^{\prime} \mathrm{E} ; 30^{\circ} 16^{\prime} \mathrm{N}$ & 7.6 & 20.1 \\
\hline 11 & Rudra Prayag-Alaknanda & $78^{\circ} 58^{\prime} \mathrm{E} ; 30^{\circ} 16^{\prime} \mathrm{N}$ & 7.6 & 19.1 \\
\hline 12 & Rudra Prayag-Mandakini & $78^{\circ} 58^{\prime} \mathrm{E} ; 30^{\circ} 16^{\prime} \mathrm{N}$ & 6.4 & 20.8 \\
\hline 13 & Rudra Prayag-Sangam & $78^{\circ} 58^{\prime} \mathrm{E} ; 30^{\circ} 16^{\prime} \mathrm{N}$ & 7.4 & 19.2 \\
\hline 14 & Srinagar & $78^{\circ} 46^{\prime} \mathrm{E} ; 30^{\circ} 13^{\prime} \mathrm{N}$ & 7.4 & 21.6 \\
\hline 15 & Kirtinagar & ND & 7.4 & 19.2 \\
\hline 16 & Dev Prayag-Alaknanda & $79^{\circ} 49^{\prime} \mathrm{E} ; 30^{\circ} 74^{\prime} \mathrm{N}$ & 7.6 & 19.8 \\
\hline 17 & Gangotri & $78^{\circ} 55^{\prime} \mathrm{E} ; 30^{\circ} 58^{\prime} \mathrm{N}$ & 7.0 & -1.6 \\
\hline 18 & Harsil & $78^{\circ} 73^{\prime} \mathrm{E} ; 31^{\circ} 03^{\prime} \mathrm{N}$ & 7.4 & 1.1 \\
\hline 19 & Gangnani & $78^{\circ} 67^{\prime} \mathrm{E} ; 30^{\circ} 91^{\prime} \mathrm{N}$ & 7.2 & 6.7 \\
\hline 20 & Maneri & $78^{\circ} 53^{\prime} \mathrm{E} ; 30^{\circ} 75^{\prime} \mathrm{N}$ & 6.9 & 8.2 \\
\hline 21 & Maneri Dam & $78^{\circ} 53^{\prime} \mathrm{E} ; 30^{\circ} 75^{\prime} \mathrm{N}$ & 7.2 & 8.1 \\
\hline 22 & Uttarkashi & $78^{\circ} 45^{\prime} \mathrm{E} ; 30^{\circ} 73^{\prime} \mathrm{N}$ & 6.9 & 10.1 \\
\hline 23 & Chinyali Saur & $77^{\circ} 49^{\prime} \mathrm{E} ; 30^{\circ} 20^{\prime} \mathrm{N}$ & 6.9 & 12.4 \\
\hline 24 & Tehri Dam & $78^{\circ} 29^{\prime} \mathrm{E} ; 30^{\circ} 23^{\prime} \mathrm{N}$ & 7.1 & 12.1 \\
\hline 25 & Dev Prayag-Bhagirathi & $79^{\circ} 49^{\prime} \mathrm{E} ; 30^{\circ} 74^{\prime} \mathrm{N}$ & 7.4 & 20.5 \\
\hline 26 & Dev Prayag - Sangam & $79^{\circ} 49^{\prime} \mathrm{E} ; 30^{\circ} 74^{\prime} \mathrm{N}$ & 7.4 & 20.3 \\
\hline 27 & Kodiyala & $79^{\circ} 04^{\prime} \mathrm{E} ; 30^{\circ} 53^{\prime} \mathrm{N}$ & 8.0 & 22.8 \\
\hline 28 & Shivpuri & $78^{\circ} 38^{\prime} \mathrm{E} ; 30^{\circ} 15^{\prime} \mathrm{N}$ & 7.7 & 18.1 \\
\hline 29 & Rishikesh-Ramjhula & $78^{\circ} 31^{\prime} \mathrm{E} ; 30^{\circ} 11^{\prime} \mathrm{N}$ & 7.8 & 19.2 \\
\hline 30 & $\begin{array}{l}\text { Rishikesh-Lakshman } \\
\text { Jhula }\end{array}$ & $78^{\circ} 31^{\prime} \mathrm{E} ; 30^{\circ} 11^{\prime} \mathrm{N}$ & 7.8 & 19.0 \\
\hline 31 & Haridwar & $78^{\circ} 13^{\prime} \mathrm{E} ; 29^{\circ} 58^{\prime} \mathrm{N}$ & 7.6 & 21.0 \\
\hline 32 & Haridwar-Har Ki Pauri & $78^{\circ} 13^{\prime} \mathrm{E} ; 29^{\circ} 58^{\prime} \mathrm{N}$ & 7.6 & 20.1 \\
\hline
\end{tabular}

ND: not defined 


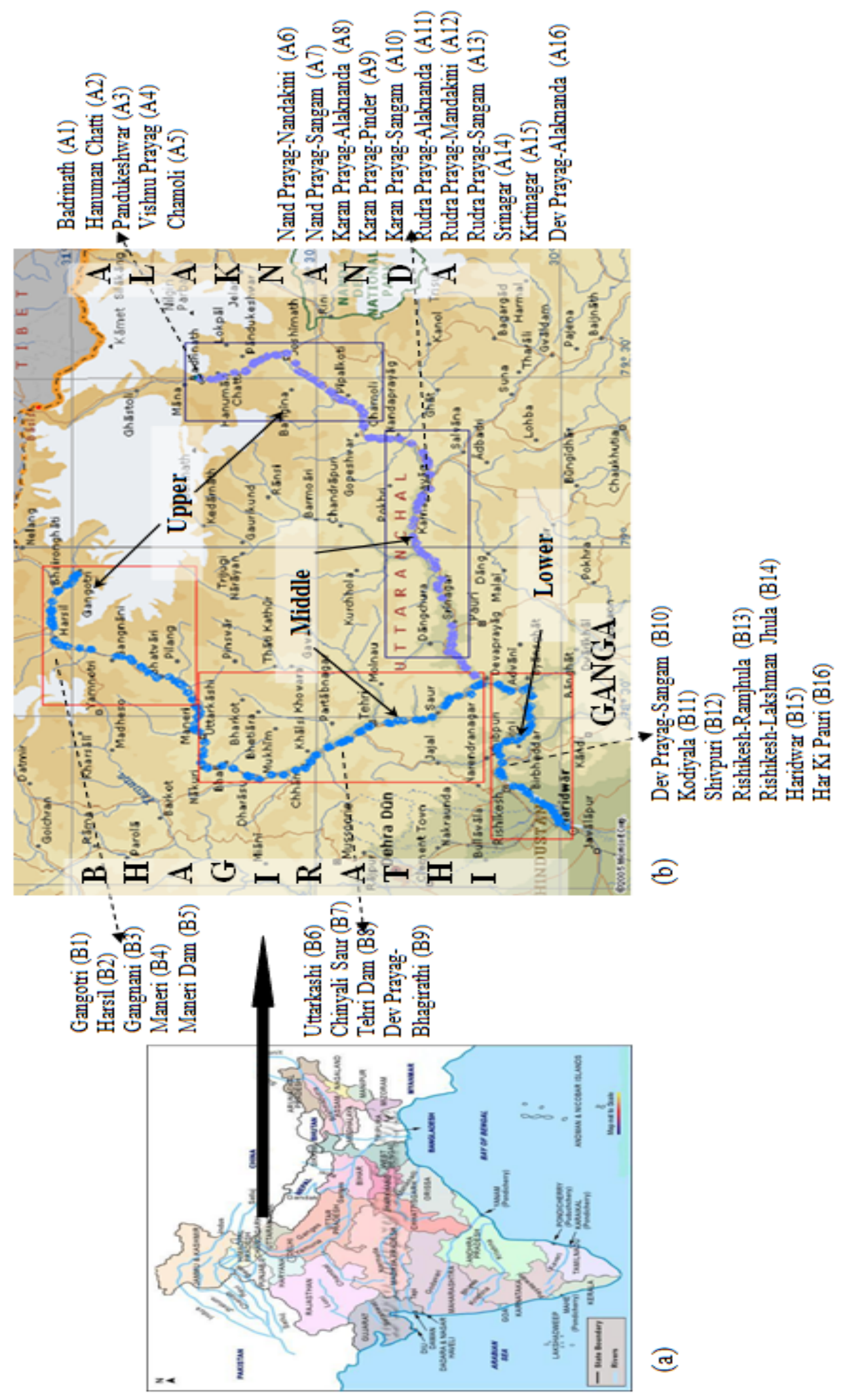

Figure 1. Location map of the study area 
Each culture was submitted to Gram stain and tested for production of catalase and coagulase. All catalase positive Gram positive cocci were subjected to complete biochemical identification as described for the genus Staphylococcus in Bergey's Manual of Systematic Bacteriology [14].

\section{Antimicrobial susceptibility testing}

Antibiotic susceptibility was determined by disc diffusion assay on Mueller Hinton agar using Kirby Bauer method [7]. The strains were separately inoculated in nutrient broth and incubated at $37^{\circ} \mathrm{C}$. Log phase cultures $\left(\approx 10^{8}\right.$ cells $\left.\mathrm{ml}^{-1}\right)$ were used for inoculation. Himedia octodiscs were used (Himedia, G-XIV and G-X-plus plus OD050) as per standard procedures. The following antibiotics were used erythromycin (10mcg), fusidic acid (10 mcg), chloramphenicol (30 mcg), vancomycin (30 mcg), methicillin $(10 \mathrm{mcg})$, novobiocin $(5 \mathrm{mcg})$, streptomycin $(25 \mathrm{mcg})$. After incubation $\left(37^{\circ} \mathrm{C}\right.$ for $48 \mathrm{~h}$ ), the plates were observed for the zone of inhibition surrounding the discs. The diameter of zone of inhibition was measured using a ruler. The zones of inhibition of test strains to various antibiotics were compared to those obtained for reference strain (procured from MTCC, IMTECH). Staphylococcus aureus MTCC 9542 was used as positive control in the study.

\section{Amplification of ribosomal DNA}

Strains were subjected to $16 \mathrm{~S}$ rDNA sequence analysis for establishment of their genotypic position. Genomic DNA was isolated using standard procedures [30]. Universal eubacterial primers 8F (5'-agagtttgatcctggctcag-3') and 492R (5'gggttaccttgttacgactt-3') were used for amplification of $16 \mathrm{~S}$ rRNA gene. The thermal cycling conditions were: initial denaturation of $3 \mathrm{~min}$ at $95^{\circ} \mathrm{C}$ followed by 35 cycles of denaturation of $1 \mathrm{~min}$ at $95^{\circ} \mathrm{C}$, annealing of $56^{\circ} \mathrm{C}$ for $1 \mathrm{~min}$, extension of $1 \mathrm{~min}$ at $72^{\circ} \mathrm{C}$ and a final extension of $10 \mathrm{~min}$ at $72^{\circ} \mathrm{C}$. A $50 \mathrm{ml}$ reaction mixture included $100 \mathrm{ng}$ of bacterial DNA as template, $1 \mathrm{mM}$ of each primer, $1.5 \mathrm{U}$ of Taq DNA polymerase and $200 \mathrm{mM}$ dNTPs. Amplified DNA was visualized in 1\% agarose.

\section{DNA sequencing and phylogenetic analysis}

The 16S rDNA sequence was determined using ABI PRISM 377 DNA sequencer. The 16S rDNA nucleotide sequences obtained in this study was submitted in GenBank database. Searches in the EMBL/Gen bank/DDBJ/PDB data libraries were performed using BLAST (blastin) [2] search algorithm in order to identity of the isolate. Sequences of the close relatives were retrieved and aligned with the newly determined sequences. Phylogenetic and molecular evolutionary analyses were conducted using MEGA version 4 software [37] and phylogenetic tree was constructed by the maximum parsimony method.

\section{Results and discussion}

$S$. aureus has been well described as one of the most widely spread human pathogens. This could be as a result of its minimal growth requirements, ability to survive long in most unfavorable environments and to find a susceptible host. In present study, several staphylococci were isolated from river Ganga, that transverse through 
difficult terrain on mountains and faces mass bathing as an age-old ritual in Uttarakhand, India.

\section{Prevalence and distribution of staphylococci in study area}

As a result of rigorous sampling and careful culturing strategies, Staphylococcus species were isolated from $28(87 \%)$ out of total 32 sites covering study area. In general, $S$. aureus is known to grow between 7 and $47^{\circ} \mathrm{C}$, with an optimum of $30-37^{\circ} \mathrm{C}(24)$. However, in present study, coagulase positive-staphylococci were isolated from sites like Hanuman Chatti, Pandukeshwar, Vishnu Prayag, and Gangnani where water temperature was in range of $1.4-5.6^{\circ} \mathrm{C}$. It is relevant to mention that human population is very low in these regions, and human interference is negligible because of heavy flow of water. Further, there were other regions completely devoid of staphylococci, like Gangotri and Harsil where water temperature was very low (i.e. $-1.6^{\circ} \mathrm{C}$ and $1.1^{\circ} \mathrm{C}$ respectively). All the three sites at Karanprayag (Karanprayag-Alaknanda, Karanprayag-Pinder, Karanprayag-Sangam), were found free from staphylococci, in spite of the fact that the temperature at Karanprayag was suitable for its growth and survival $\left(17.6^{\circ} \mathrm{C}, 20.1^{\circ} \mathrm{C}\right.$ and $\left.22.8^{\circ} \mathrm{C}\right)$.

Earlier, Bilgrami and Kumar [8] studied the bacterial contamination in water of the River Ganga at other regions like Bhagalpur, and found a marked correlation between bacterial density and physico-chemical quality of water including temperature and $\mathrm{pH}$. In this study, the $\mathrm{pH}$ of water at the time of sampling (April, 2008) ranged from 6.4 to 8.0, while the temperature ranged from $-1.6^{\circ} \mathrm{C}$ to $22.8^{\circ} \mathrm{C}$ for different sites. Further, Bilgrami and Kumar [8] also isolated several Staphylococcus aureus along with several other pathogenic bacterial strains from Ganga. Similarly, in present work, staphylococci were isolated from $87 \%$ of the sampling sites, while $62.5 \%$ of the samples had $S$. aureus. Therefore it may be concluded that direct consumption of untreated Ganga water and bathing, in stretch of flow may possess serious health risk.

\section{Isolation, enumeration and characterization of staphylococci}

The viable counts for Staphylococcus spp. ranged from $100 \mathrm{cfu} / \mathrm{ml}$ to $1900 \mathrm{cfu} / \mathrm{ml}$ (Table 2). The highest value was recorded from Haridwar-Har ki Pauri (1900 cfu/ml) on BP agar. These sites witness holy dip and mass bathing by a large number of pilgrims as an old age ritual in India, which is a constant source of contamination of water bodies [31]. Hence, the higher counts at lower stretch of the study area might be accounted to anthropogenic activities due to which high numbers of pathogens are introduced in the river water. Other ten less populated sites had viable counts as low as $100 \mathrm{cfu} / \mathrm{ml}$, which support the hypothesis.

Baird Parker agar medium was observed to be a better medium for isolation of staphylococci from river water as compared to mannitol salt agar as evidenced by low cfu counts obtained on MS agar. Further, BP agar medium gave excellent recovery of Staphylococcus spp. and was inhibitory to other organisms. Baird-Parker agar has been recommended for the isolation of staphylococci from recreational water resources for its greater diagnostic qualities [33]. Also its value in ecological studies on the occurrence and development of $S$. aureus has been confirmed by other workers [10]. Interestingly, $\mathrm{BP}$ and MS, both media were found to be biased for the isolation of staphylococci at several sites. As example, no colonies were obtained on BP medium, but appeared on MS agar medium at sites like Hanuman Chatti, Tehri Dam and DevPrayag-Sangam. 
Conversely, at sites like Rudra Prayag-Alaknanda, Kirtinagar, Dev Prayag-Alaknanda and Dev Prayag-Bhagirathi, no colony appeared on MS medium, while staphylocooci were isolated on BP agar. This may possibly be because of the fact that species of Staphylococcus are known to exhibit different growth pattern on BP and MS agar respectively. In this study, species other than $S$. aureus were isolated from different sites of the study (Table 2). Earlier, Bannerman [6] also observed that staphylococci other than $S$. aureus grow well on the BP agar medium.

A total of 128 staphylococcal strains were isolated from River Ganges. Majority of them belonged to three species of staphylococci, the most common being $S$. aureus $(88$, $68.75 \%$ ) detected from 20 sites, followed by $S$. hominis $(21,16.4 \%)$ from 14 sites and $S$. aegilis $(8,6.25 \%)$ from 8 sites. Few strains could not be assigned to species level, therefore grouped as 'other staphylococci'. Earlier also, S. aureus have been isolated from rivers and other aquatic habitats [19] even so that it was found in correlation to total coliforms for estimation of sewage pollution in northern coast of the Saronicos Gulf in Greece [11]. Also, S. aureus have been reported from other regions of river Ganga, along with other bacterial pathogens [8], though antibiotic sensitivity profile received little attention.

In addition, there are many reasons for potential concern over the presence of $S$. aureus in recreational and drinking water resources as $S$. aureus has ability to survive for longer period in water [3]. Although $S$. aureus is an important pathogen, many healthy people carry it as part of the normal population of micro-organisms associated with the nose, throat, perineum or skin and the nasal passages are also reported to harbour $S$. aureus in $10-50 \%$ of the healthy population [15]. Semwal and Akolkar [31] proposed that a considerable percentage of pilgrims visiting holy places and sacred Himalayan Rivers for bathing, carry skin and other communicable diseases. Additionally, some of these pilgrims settle nearby river banks and their daily routine near the water course becomes a constant source of contamination of the water bodies. The high population of $S$. aureus in River Ganga can be accounted to these anthropogenic activities. $S$. aureus in drinking water may also serve as a source for colonizing residents exposed to contaminated water [19].

Table 2. Quantification of Staphylococci species from the different sites of River Ganga by direct plating $(\mathrm{cfu} / \mathrm{ml})$ method

\begin{tabular}{llll}
\hline $\begin{array}{l}\text { Site } \\
\text { Number }\end{array}$ & $\begin{array}{l}\text { Vaird Parker agar } \\
\text { medium }\end{array}$ & $\begin{array}{l}\text { Mannitol salt agar } \\
\text { medium }\end{array}$ & *Species \\
\hline 1 & 200 & 100 & Sae \\
2 & - & 100 & Sau \\
3 & 800 & 300 & Sau; Sho; Ssp \\
4 & 300 & 200 & Sau \\
5 & 600 & 700 & Sau; Ssp \\
6 & 100 & 100 & Sho \\
7 & 1200 & 300 & Sae; Sho \\
8 & - & - & - \\
9 & - & - & - \\
10 & - & - & - \\
11 & 100 & - & Sau \\
\hline
\end{tabular}




\begin{tabular}{llll}
\hline 12 & 1300 & 500 & Sau; Sho \\
13 & 900 & 300 & Sae; Sau; Sho; Ssp \\
14 & 1000 & 700 & Sae; Sau; Sho \\
15 & 100 & - & Sho \\
16 & 700 & - & Sae; Sau \\
17 & - & - & - \\
18 & - & - & - \\
19 & 600 & 400 & Sau; Sho; Ssp \\
20 & 1200 & 100 & Sae; Sau; Sho \\
21 & 900 & 100 & Sau \\
22 & 500 & 200 & Sho; Ssp \\
23 & 100 & 200 & Sau; Sho \\
24 & - & 100 & Ssp \\
25 & 300 & - & Sau; Ssp \\
26 & - & 200 & Sae \\
27 & 800 & 700 & Sau \\
28 & 1100 & 1000 & Sae; Sau; Sho; Ssp \\
29 & 1200 & 100 & Sau; Sho \\
30 & 1400 & 1100 & Sau; Ssp \\
31 & 700 & 600 & Sau; Sho; Ssp \\
32 & 1900 & 1400 & Sau; Ssp \\
\hline- Absent & & & \\
$*$ Sae: Staphylococcus aegilis; Sau: S. aureus; Sho: S. hominis; Ssp: other staphylococci
\end{tabular}

\section{Incidence and distribution of MRSA}

Results of antibiotic susceptibility testing showed multidrug resistance and variability in sensitivity and resistance patterns. Earlier also other workers have observed similar results for susceptibility patterns for staphylococci $[13,21,26]$. Prevalence of multidrug resistant staphylococci was recorded in river Ganga in present study. All the $S$. aureus isolates were resistant to either one or more of the antibiotics used in this study and complete sensitivity was not observed for any of the antimicrobial agent tested (Figure 2a). Majority of the isolates were resistant for erythromycin, while $17.6 \%$ of $S$. aureus were resistant to methicillin. The number of isolates resistant to each antimicrobial agent were erythromycin $(n=69)$, augmentin $(n=49)$, streptomycin $(n=43)$, tetracycline $(n=41)$, fusidic acid $(n=39)$, novobiocin $(n=38)$, gentamicin $(n$ $=28)$, chloramphenicol $(n=27)$, penicillin $-\mathrm{n}(\mathrm{n}=24)$, ciprofloxacin $(\mathrm{n}=22)$, methicillin $(\mathrm{n}=20)$ and vancomycin $(\mathrm{n}=5)$. Thus the $S$. aureus from River Ganga in Uttarakhand, India showed high resistance to multiple drugs. Earlier, Tolba et al. [38] compared the survival ability of MRSA between saline and river waters, and concluded that MRSA may not survive well in river water as compared to sea water. Therefore, presence of $17.6 \%$ MRSA should be supposed as underestimation of contamination status due to its poor viability in river water, as actual count may be higher than obtained. Although the number of methicillin resistant $S$. aureus was low, the detection of such strains from river Ganga is alarming. Pertaining to the fact that prevalence of MRSA in hospitals has been increasing in India [27], its presence in river Ganga presents the possibility of dissemination in large community. Smith et al. [34] also emphasized that MRSA, besides having established itself as a major hospital pathogen, 
is now beginning to prevail in a wider community. Despite the development and introduction of several antimicrobial agents, MRSA infections remain an important cause of concern for the general public and physicians alike [23].

Further the isolation of MRSA from lower stretch of the study area was quite high as compared to those from higher stretch of the study area. Infact $93 \%$ of MRSA were isolated from the lower stretch of the study area. The prevalence of MRSA in the lower stretch of the study area can be also attributed to the fact that the lower sites experience higher anthropogenic activities in the form holy baths. So, these resistant strains might be introduced in the river water due to such activities. Asymptomatic carriage of MRSA in individuals using such waters allows the contamination of such waters with MRSA organisms. Such contaminated water may subsequently act as a transient environmental reservoir for MRSA, thus allowing the spread of MRSA among the population who use such sources for recreational and/or religious purposes [38]. Further the staphylococci isolated from the upper regions showed $90-95 \%$ sensitivity to most of the antimicrobials used in this study. This indicates that the strains indigenous to the Ganges have not acquired the resistance genes. Also, the low temperature conditions in the upper regions do not support the growth and survival of MRSA. However, if the contamination of river remains unchecked, soon the number of MRSA might increase the number of sensitive $S$. aureus. Regecová et al. [29] suggested that a rational use of antibiotics, complying with preventive measures in environmental hygiene and monitoring of existing resistance to antibiotics are very important weapons against spreading of antibiotic resistance.

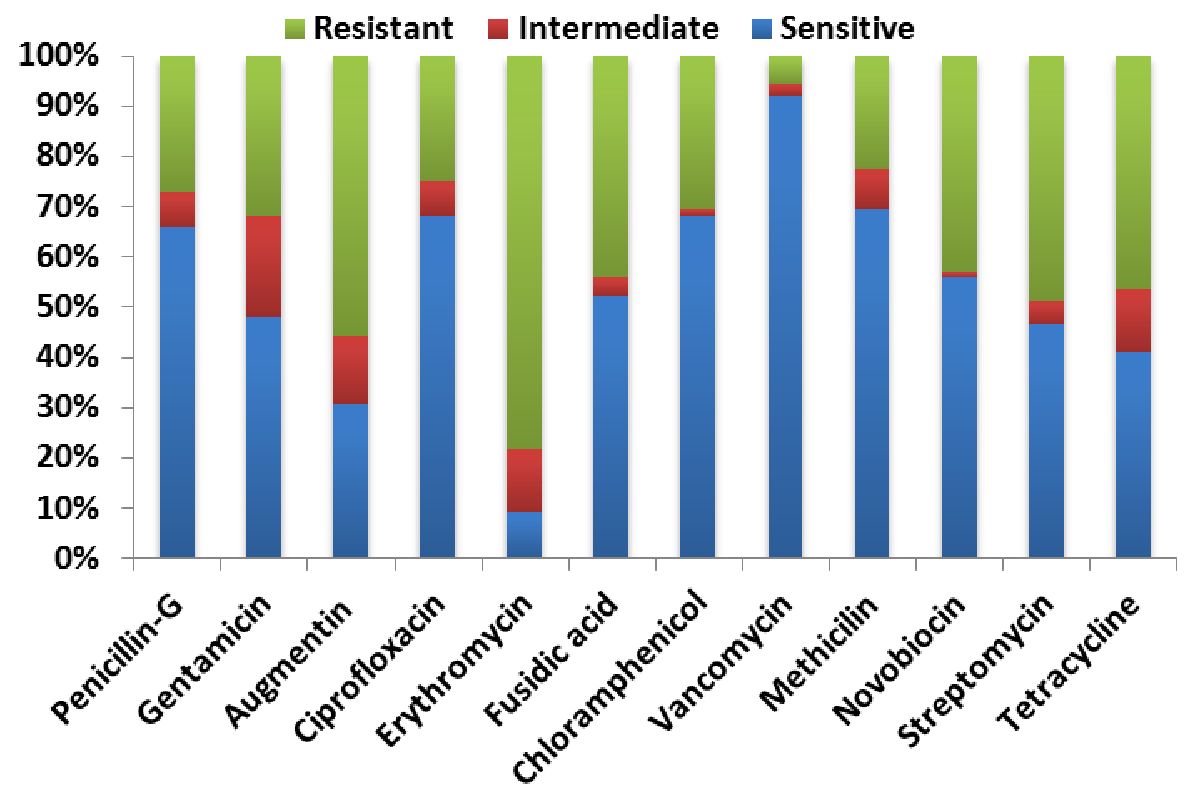

Figure 2a. Antibiotic susceptibility pattern of S. aureus isolates from River Ganga

As a matter of fact, most of the $S$. aureus strains are known to be resistant to Penicillin-G [15], still very low resistance to Penicillin-G was observed in our study. The high sensitivity of $S$. aureus from river Ganga to this antibiotic might be attributed to non-pathogenicity and/or natural site of isolation of these strains. Although the vast preponderance of interest has been centred about the change from drug-sensitive to 
drug-resistant forms, certain epidemiological experiences suggest that drug-resistant bacteria sometimes revert to sensitive or are later crowded out by originally sensitive forms [12].

\section{Antimicrobial susceptibility of S. hominis, S. aegilis and other staphylococci}

Approximately $10 \%$ of the $S$. hominis strains were resistant to methicillin (Figure $2 b)$. All the strains were sensitive to vancomycin and ciprofloxacin. The number of strains resistant to each antimicrobial agent were penicillin-G $(n=4)$, gentamicin $(n=$ $2)$, augmentin $(n=11)$, erythromycin $(n=12)$, fusidic acid $(n=9)$, chloramphenicol ( $n$ $=11)$, methicillin $(n=3)$, novobiocin $(n=7)$, streptomycin $(n=7)$ and tetracycline $(n=$ 8 ). On the other hand all the 8 strains of $S$. aegilis were sensitive to methicillin, vancomycin, augmentin and penicillin-G (Figure 2c). Further lesser strains exhibited resistance for rest of the antibiotics. The number of strains resistant to each antimicrobial agent were gentamicin $(n=2)$, erythromycin $(n=3)$, ciprofloxacin $(n=$ $2)$, novobiocin $(n=3)$, streptomycin $(n=2)$ and tetracycline $(n=1)$. The other staphylococci showed complete sensitivity to gentamicin, erythromycin, vancomycin and methicillin (Figure 2d). 55\% and 35\% resistance was observed for tetracycline and novobiocin respectively.

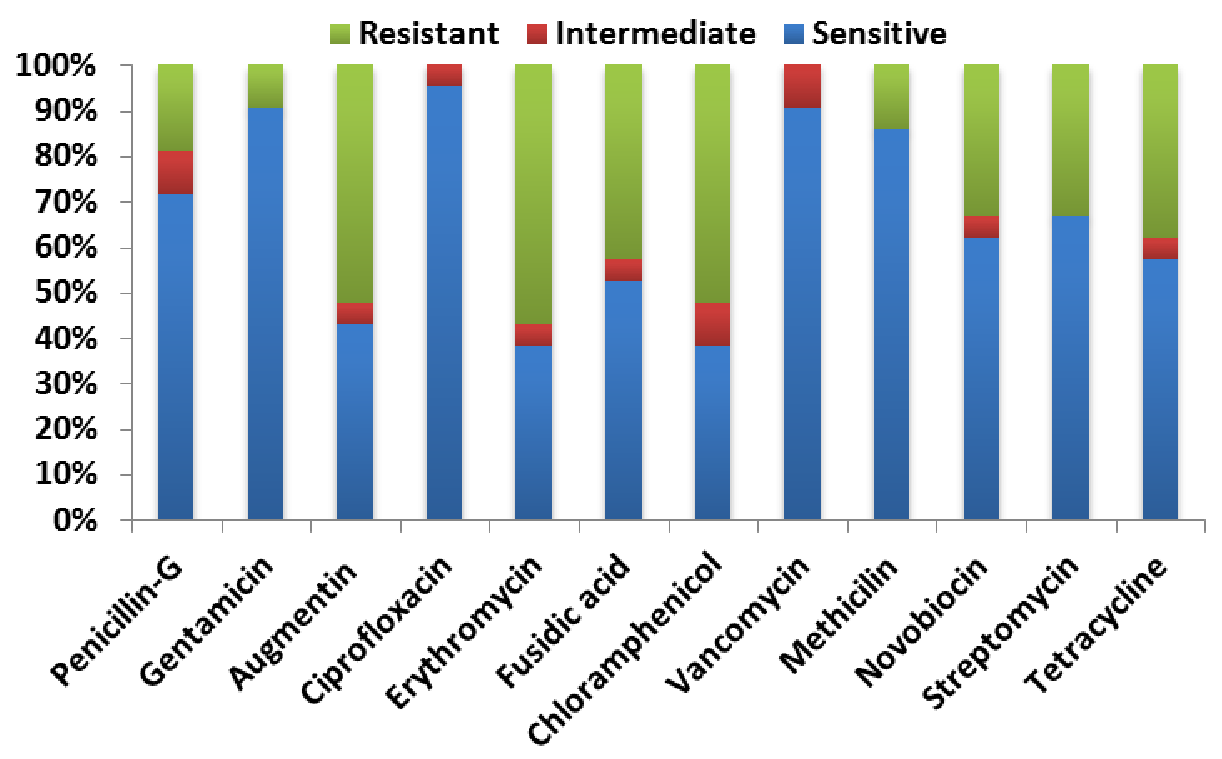

Figure 2b. Antibiotic susceptibility pattern of S. hominis isolates from River Ganga

\section{Phylogenetic characterization of selected multiple drug resistant staphylococci}

Selected multidrug resistant staphylococci isolated in this study (WB1P, RA3U1 and WB3T3) were subjected to $16 \mathrm{~S}$ rDNA based molecular analysis to establish their phylogenetic position. These strains were isolated from Gangotri, Pandukeshwar and Gangnani respectively, all sites from upper region of the Ganges. A phylogenetic tree (Figure 3) was constructed based on evolutionary distances that were calculated with the Kimura two-parameter model. Alignment positions with insertions or deletions were excluded from the calculations. 16S rRNA gene sequence (NCBI GenBank accession numbers - EU882824, EU882823, EU882825 respectively) analysis indicated that the 
strains WB1P, RA3U1 and WB3T3 were phylogenetically related to members of the genus Staphylococcus; however the three strains clustered together in a separate minor clade. Other genera of family Staphylococcaceae were also taken into account in phylogenetic analysis, which formed a separate mega cluster. The biochemical properties of the strains are presented in table 3.

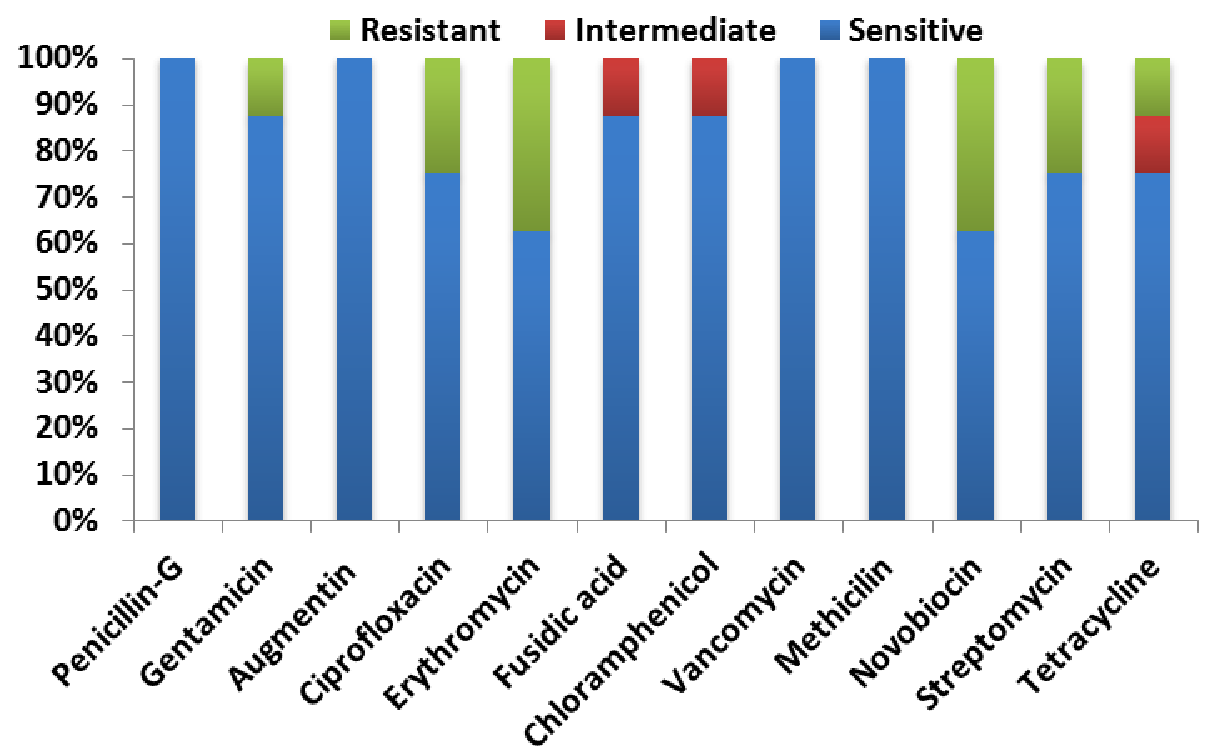

Figure 2c. Antibiotic susceptibility pattern of S. aegilis isolates from River Ganga

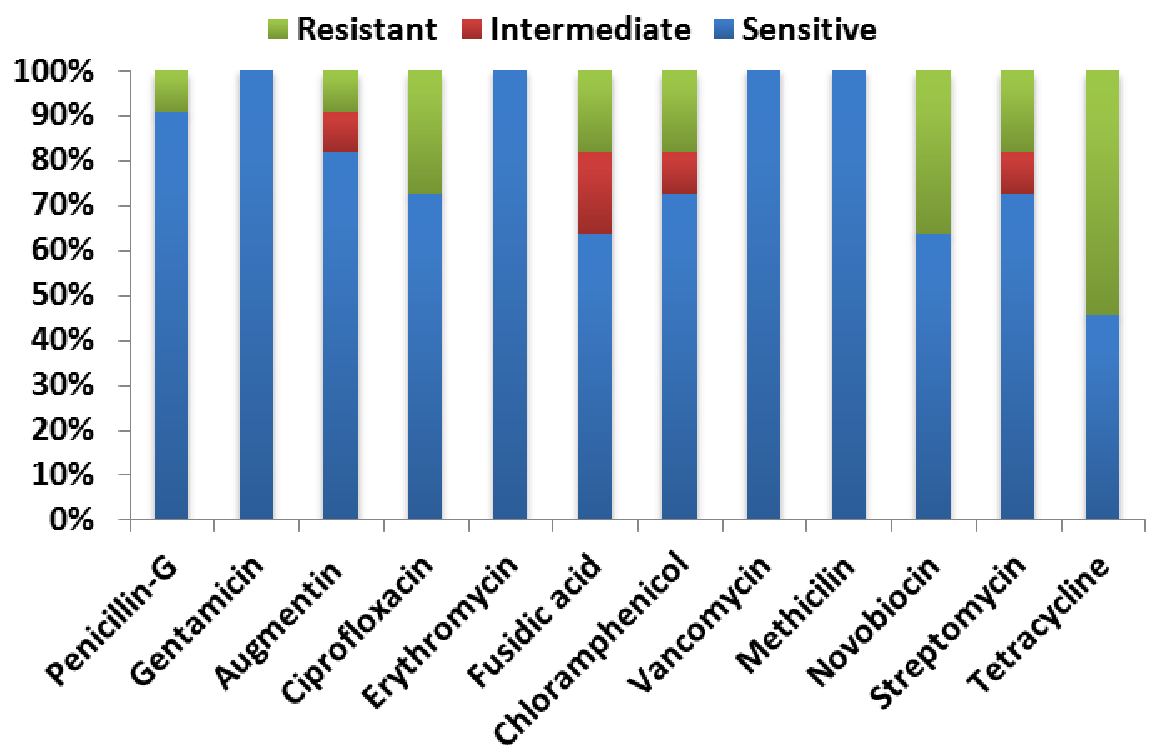

Figure 2d. Antibiotic susceptibility pattern of other staphylococci isolated from River Ganga

These strains were resistant to methicillin, penicillin-G, tetracycline, streptomycin and genatmicin. The high resistance of these staphylococci for most of the antimicrobial agents should be a matter of concern as these were isolated from less-populated upper 
region of River Ganges. Hence it is difficult to predict whether these strains were indigenous to this river system or introduced through human activities.

Table 3. Morphological and physiological characteristics of selected multiple drug resistant staphylococci isolated from River Ganga

\begin{tabular}{|c|c|c|c|c|}
\hline Characteristic & $\begin{array}{l}\text { Staphylococcus } \\
\text { sp. RA3U1 }\end{array}$ & $\begin{array}{l}\text { Staphylococcus } \\
\text { sp. WB1P }\end{array}$ & $\begin{array}{l}\text { Staphylococcus } \\
\text { sp. WB3T3 }\end{array}$ & $\begin{array}{l}\text { S. aureus } \\
\text { (MTCC 9542) }\end{array}$ \\
\hline Gram reaction & + & + & + & + \\
\hline Shape & cocci & cocci & cocci & cocci \\
\hline Indole Test & + & - & - & + \\
\hline Methyl Red Test & - & + & + & + \\
\hline Voges Proskauer Tests & - & + & + & - \\
\hline Citrate Utilization & + & - & - & - \\
\hline $\begin{array}{l}\text { Gas Production from } \\
\text { Glucose }\end{array}$ & + & - & + & + \\
\hline Casein Hydrolysis & - & - & - & - \\
\hline Urea Hydrolysis & + & - & + & - \\
\hline Nitrate Reduction & + & + & + & + \\
\hline $\mathrm{H}_{2} \mathrm{~S}$ Production & - & - & - & - \\
\hline Coagulase & + & - & - & + \\
\hline Cytochrome Oxidase & - & - & - & - \\
\hline Catalase Test & + & + & + & - \\
\hline $\begin{array}{l}\text { Oxidation/Fermentation } \\
(\mathrm{O} / \mathrm{F})\end{array}$ & Fermentative & Fermentative & Fermentative & Fermentative \\
\hline Gelatin Hydrolysis & + & + & - & + \\
\hline Arginine dihydrolase & - & - & - & - \\
\hline Lysine decarboxylase & - & - & - & - \\
\hline Ornithine decarboxylase & - & - & - & - \\
\hline Carbon source utilization & & & & \\
\hline Adonitol & + & - & - & - \\
\hline Arabinose & + & + & + & + \\
\hline Cellobiose & - & - & - & - \\
\hline Dextrose & + & + & + & + \\
\hline Dulcitol & - & + & - & + \\
\hline Fructose & + & - & - & + \\
\hline Galactose & - & - & + & + \\
\hline Inositol & - & - & - & - \\
\hline Lactose & - & + & + & + \\
\hline Maltose & + & + & - & + \\
\hline Mannitol & + & - & + & + \\
\hline Melibiose & - & - & + & + \\
\hline Raffinose & + & - & - & + \\
\hline Rhamnose & + & + & + & + \\
\hline Salicin & - & + & - & + \\
\hline Sorbitol & - & - & - & + \\
\hline Sucrose & + & + & + & + \\
\hline Trehalose & + & + & - & + \\
\hline Xylose & + & - & - & + \\
\hline Temperature tolerance & $15^{\circ} \mathrm{C}-45^{\circ} \mathrm{C}$ & $10^{\circ} \mathrm{C}-37^{\circ} \mathrm{C}$ & $15^{\circ} \mathrm{C}-45^{\circ} \mathrm{C}$ & $25^{\circ} \mathrm{C}-37^{\circ} \mathrm{C}$ \\
\hline $\mathrm{pH}$ range & $5.0-8.0$ & $5.7-8.5$ & $5.0-9.0$ & $5.7-8.0$ \\
\hline $\mathrm{NaCl}$ tolerance upto & $8.0 \%$ & $9.0 \%$ & $11 \%$ & $10.0 \%$ \\
\hline $\begin{array}{l}\text { Growth under anaerobic } \\
\text { condition }\end{array}$ & - & - & - & - \\
\hline
\end{tabular}




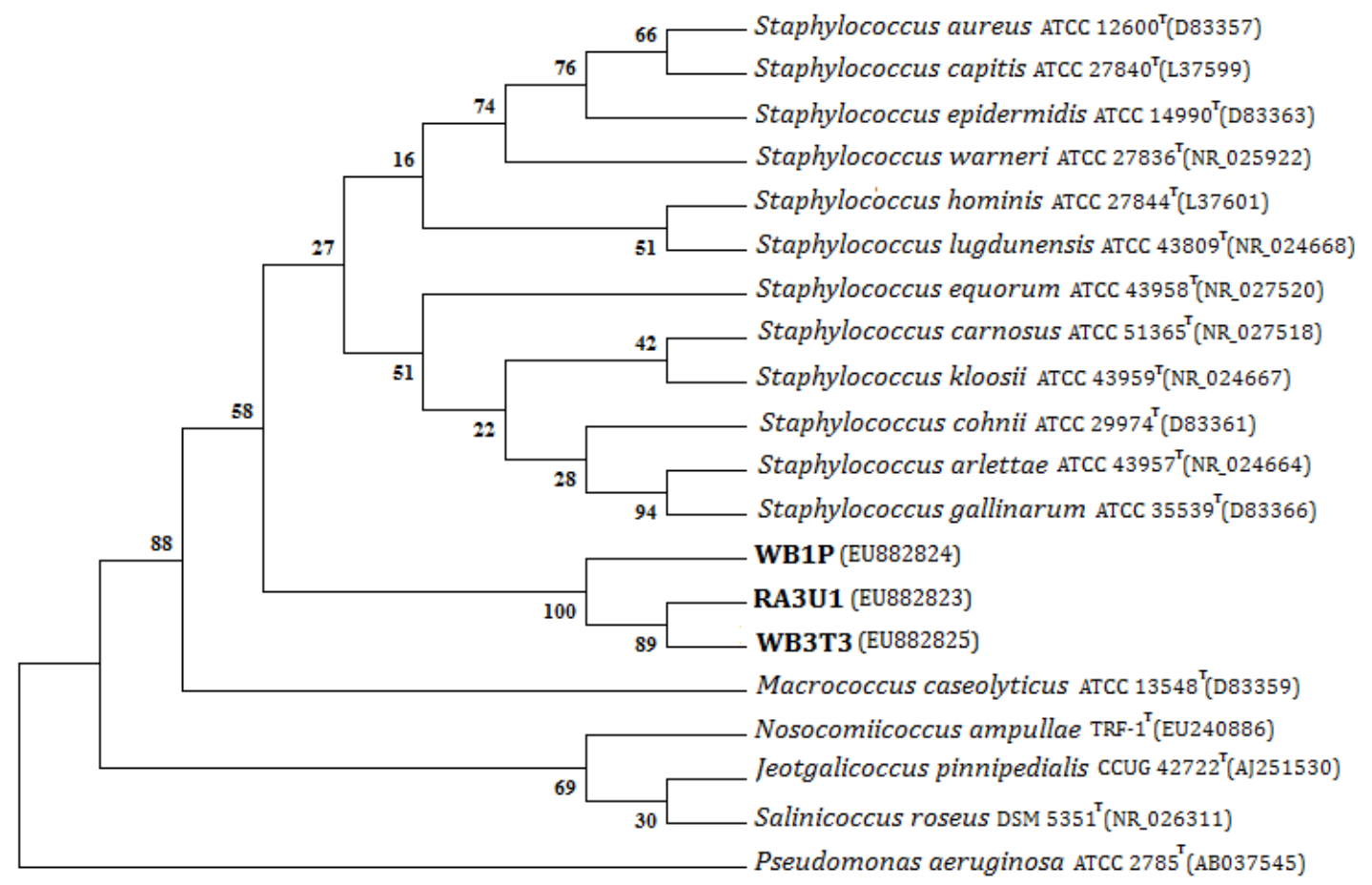

Figure 3. Phylogenetic relationship between RA3U1; WB1P; WB3T3 and representative

Staphylococcus species based on partial $16 S$ rDNA sequences constructed by using the maximum parsimony method. Sequence accession numbers are given in parentheses. Numbers at branching points refer to bootstrap values (1000 resamplings). Pseudomonas aeruginosa was used as outgroup

Although there are some reports on the detection of $S$. aureus from river Ganga [8, $35]$, to the best of our knowledge this is the first report on the isolation, prevalence and antimicrobial susceptibility pattern of staphylococci from the Ganga river system of Uttarakhand comprising of 32 sampling sites. Considering the facts that multiple antibiotic sensitive $S$. aureus is one of the most widely spread human pathogen, the havoc it causes on life and subsequently on the economy; it is imperative to determine its incidence and antibiogram in our environment for adequate control and treatment.

Acknowledgements. The authors are grateful to Uttarakhand State Council of Science and Technology for grant received to carry out this study. The authors are also thankful to the Management of S.B.S.P.G.I., Dehradun (India) for providing necessary research facilities.

\section{REFERENCES}

[1] Ahmed, W., Neller, R., Katouli, M. (2005): Host species-specific metabolic fingerprint database for Enterococci and Escherichia coli and its application to identify sources of fecal contamination in surface waters. Appl. Environ. Microbiol. 71: 4461-4468. 
[2] Altschul, S.F., Madden, T.L., Schaffer, A.A., Zhang, J., Zhang, Z., Miller, W., Lipman, D.J. (1997): Gapped BLAST and PSI-BLAST: a new generation of protein database search programs. Nuc. Acid Res. 25: 3389-3402.

[3] Anon. (1972): Staphylococcal food poisoning; Milwaukee; Wisconsin. Morb. Mort. Week Rep. 21: 422-423.

[4] APHA. (1992): American Public Health Association. Standard Methods for the Examination of Water and Wastewater. $18^{\text {th }}$ APHAAWWAWPCF: Washington DC.

[5] Baird-Parker, A.C. (1962): An improved diagnostic and selective medium for isolating coagulase-positive Staphylococci. J. Appl. Bacteriol. 25: 12-19.

[6] Bannerman, T.L. (2003): Staphylococcus; Micrococcus; and other catalasepositive cocci that grow aerobically. In: Murray, P.R., Baron, E.J., Jorgensen, J.H., Pfaller, M.A., Yolken, R.H. (eds). Manual of Clinical Microbiology. American Society for Microbiology, Washington, D.C.

[7] Bauer, A.W., Kirby, W.M.M., Sherris, J.C., Turck, M. (1966): Antibiotic susceptibility testing by a standardized single disk method. Amer. J. Clin. Pathol. 45: 493-496.

[8] Bilgrami, K.S., Kumar, S. (1998): Bacterial contamination in water of the River Ganga and its risk to human health. Int. J. Environ. Heal. Res. 8: 5-13.

[9] Cunha, B.A. (2005): Methicillin-resistant Staphylococcus aureus: clinical manifestations and antimicrobial therapy. Clin. Microbiol. Infect. 11: 33-42.

[10] de Waart, J., Mossel, D.A.A., Ten-Broeke, R., van de Moosdijk, A. (1968): Enumaration of Staphylococcus aureus in foods with special reference to egg-yolk reaktion and mannitol negative mutants. J. Appl. Bact. 31: 276- 285.

[11] Efstratiou, M.A., Mavridou, A., Richardson, S.C., Papadakis, J.A. (1998): Correlation of bacterial indicator organisms with Salmonella spp.; Staphylococcus aureus and Candida albicans in sea water. Lett. Appl. Microbiol. 26: 342-346.

[12] Fairbrother, R.W., Parker, L., Eaton, B.R. (1954): The Stability of PenicillinaseProducing Strains of Staphylococcus Aureus. J. Gen. Microbiol. 10: 309-316.

[13] Goel, M.M., Singh, A.V., Mathur, S.K., Singh, M., Singhal, S., Chaturvedi, U.C. (1991): Resistant coagulase negative staphylococci from clinical samples. Ind. J. Med. Res. 93: 350-352.

[14] Holt, J.G., Kreig, N.R., Sneath, P.H.A., Staley, J.T., Williams, S.T. (1994): In: Wilkins, W., Baltimore, D. (eds) Bergey's Manual of Determinative Bacteriology. pp. 151-157.

[15] Kloos, W.E. (1980): Natural populations of the genus Staphylococcus. Ann. Rev. Microbiol. 34: 559-592.

[16] Kowalski, T.J., Berbari, E.F., Osmon, D.R. (2005): Epidemiology; treatment; and prevention of community-acquired methicillin-resistant Staphylococcus aureus infections. Mayo. Clin. Proc. 80: 1201-1207.

[17] Kruse, H., Sorum, H. (1994): Transfer of multiple drug resistance plasmids between bacteria of diverse origins in natural microenvironments. Appl. Environ. Microbiol. 60: 4015-4021.

[18] Lata, P., Ram, S., Agrawal, M., Shanker, R. (2009): Enterococci in river Ganga surface waters: Propensity of species distribution; dissemination of antimicrobialresistance and virulence-markers among species along landscape. BMC Microbiol. 9: 140-149. 
[19] Lechevallier, M.W., Seidler, R.J. (1980): Staphylococcus aureus in Rural Drinking Water. Appl. Environ. Microbiol. 30: 739-742.

[20] Mariano, V., McCrindle, C.M.E., Cenci-Goga, B., Picard, J.A. (2009): Casecontrol study to determine whether River water can spread tetracycline resistance to unexposed Impala (Aepyceros melampus) in Kruger National Park (South Africa). Appl. Envriron. Microbiol. 75: 113-118.

[21] Mohan, U., Jindal, N., Aggarwal, P. (2002): Species distribution and antibiotic sensitivity pattern of coagulase negative staphylococci isolated from various clinical specimens. Ind. J. Med. Microbiol. 20: 45-46.

[22] Nautiyal, C.S. (2009): Self-purificatory Ganga water facilitates death of pathogenic Escherichia coli O157:H7. Curr. Microbiol. 58: 25-29.

[23] Neela, V., Sasikumar, M., Ghaznavi, G.R., Zamberi, S., Mariana, S. (2008): In vitro activities of 28 antimicrobial agents against Methicillin-resistant Staphylococcus aureus (MRSA) from clinical setting in Malaysia. SouthEast Asian J. Trop. Med. Public Health. 39: 885-892.

[24] Notermans, S., Heuvelman, C.J. (1983): Combined effect of water activity; pH and sub-optimal temperature on growth and enterotoxin production of Staphylococcus aureus. J. Food Sci. 48: 1832-1835.

[25] Okeke, I.N., Klugman, K.P., Bhutta, Z.A., Duse, A.G., Jenkins, P., O’Brien, T.F., Pablos-Mendez, A., Laxminarayan, R. (2005): Antimicrobial resistance in developing countries. II. Strategies for containment. Lancet. Infect. Dis. 5: 568580.

[26] Pathak, J., Udgaonkar, U., Kulkarni, R.D., Pawan, S.W. (1994): Study of Coagulase negative staphylococci and their incidence in human infections. Ind. J. Med. Microbiol. 12(2): 90-95.

[27] Pulimood, T.B., Lalitha, M.K., Jesudason, M.V., Pandian, R., Selwyn, J., John, T.J. (1996): The spectrum of antimicrobial resistance among methicillin resistant Staphylococcus aureus (MRSA) in a tertiary care centre in India. Ind. J. Med. Res. 103: 212-215.

[28] Ram, S., Vajpayee, P., Shanker, R. (2007): Prevalence of multi-antimicrobialagent resistant; shiga toxin and enterotoxin producing Escherichia coli in surface waters of river Ganga. Environ. Sci. Technol. 41(21): 7383-7388.

[29] Regecová, I., Pipová, M., Jevinová, P., Popelka, P., Kožárová, I. (2009): Determination of sensitivity of staphylococcal isolates from fish meat against selected antibiotics. Folia Veterinaria. 53, 37-39.

[30] Sambrook, J., Russel, D. (2001): Molecular Cloning: A Laboratory Manual. Cold Spring Harbor Laboratory Press; Cold Spring Harbor NY; U.S.A.

[31] Semwal, N., Akolkar, P. (2006): Water quality assessment of sacred Himalayan Rivers of Uttarakhand. Curr. Sci. 91: 486-496.

[32] Shah, M.M., Iihara, H., Noda, M., Song, S.X., Nhung, P.H., Ohkusu, K., Kawamura, Y., Ezaki, T. (2007): dnaJ gene sequence-based assay for species identification and phylogenetic grouping in the genus Staphylococcus. Int. J. Syst. Evol. Microbiol. 57: 25-30.

[33] Smith, B.A., Baird Parker, A.C. (1964): The use of sulfamethazine for inhibiting Proteus spp. on Baird-Parker's isolation medium for Staphylococcus aureus. J. Appl. Bact. 27: 78-82.

[34] Smith, S.I., Opere, B., Goodluck, H.T., Akindolire, O.T., Folaranmi, A., Odekeye, O.M., Omonigbehin, E.A. (2009): Antibiotic susceptibility pattern of 
Staphylococcus species isolated from telephone receivers. Singapore Med. J. 50(2); 208-211.

[35] Sood, A., Singh, K.D., Pandey, P., Sharma, S. (2008): Assessment of bacterial indicators and physicochemical parameters to investigate pollution status of Gangetic river system of Uttarakhand (India). Ecol. Indicat. 8: 709-717.

[36] Stengren, S.R.; Starzyk, M.J. (1984): A modified medium for recovery of Staphylococcus aureus from water. Microbios. 41: 191-203.

[37] Tamura, K., Dudley, J., Nei, M., Kumar, S. (2007): MEGA4: Molecular Evolutionary Genetics Analysis (MEGA) software version 4.0. Mol. Biol. Evol. 24: 1596-1599.

[38] Tolba, O., Loughrey, A., Goldsmith, C.E., Millar, B.C., Rooney, P.J., Moore, J.E. (2008): Survival of epidemic strains of healthcare (HA-MRSA) and communityassociated (CA-MRSA) meticillin-resistant Staphylococcus aureus (MRSA) in river-; sea- and swimming pool water. Int. J. Hyg. Environ. Health. 211: 398-402.

[39] Turnidge, J. (2004): Antibiotic use in animals-prejudices; perceptions and realities. J. Antimicrob. Chemother. 53: 26-27.

[40] van den Bogaard, A.E. (1997): Antimicrobial resistance-relation to human and animal exposure to antibiotics. J. Antimicrob. Chemother. 40: 453-454.

[41] White, D.G., Acar, J., Anthony, F., Franklin, A., Gupta, R., Nicholls, T., Tamura, Y., Thompson, S., Threlfall, E.J., Vose, D., van Vuuren, M., Wegener, H.C., Costarrica, M.L. (2001): Antimicrobial resistance: standardisation and harmonisation of laboratory methodologies for the detection and quantification of antimicrobial resistance. Rev. Sci. Tech. 20: 849-858.

[42] Young, H.K. (1993). Antimicrobial resistance spread in aquatic environments. $J$. Antimicrob. Chemother. 31, 627-635. 